\title{
The Gender Wage Gap in Africa: Theoretical and Empirical Evidence
}

\author{
Manga Engama \\ ESSEC, University of Douala \\ Cameroon
}

\begin{abstract}
:
This study measures the gender wage gap in Africa in order to determine if there is a homogeneous treatment of women in their different jobs. We also perform a theoretical and empirical review and briefly present the results of studies carried out in Africa. The analysis of the gender wage gap is necessary to identify discrimination mechanisms and shows that although women have the same training as trained as men, they remain discriminated against as regards wages. The econometric analyses in this study conclude in line with estimates carried out in Cameroon that the women earn lower wages relative to men, showing that they are victims of considerable wage discrimination. However, although wage gaps are identified in all African sub-regions, they are highest in North Africa. Also, studies performed in this part of the continent reveal a glass ceiling effect. The gender wage gap is therefore heterogeneous in the African job market.
\end{abstract}

Key words: wage gap, male, female, Africa, Cameroon

Classification JEL: J16, J24, J31, O12, O55

\section{Introduction}

The gender wage gap has been the object of many studies at the global level in recent years. In fact, since the Seventies, the phenomenon of discrimination has marked economic thinking at the theoretical and empirical levels with studies by Oaxaca (1973), Blinder (1973), Koenker and Bassett (1978). These studies that focused on the decomposition of the wage gap have been extended, and recent studies use the quantile regression technique of Machado and Mata (2005) to analyze the gender wage gap

This study does a non-exhaustive review of the theoretical and empirical studies on the wage gap in Africa. In fact, the principle of equity is violated by the fact that individuals considered identical at the economic level are treated differently. This is known as discrimination. Discrimination is based on a non-economic characteristic and thus has no systematic relationship with productivity, abilities, and performance. Discrimination is generally related to gender (Antecol, Jong and Steinberger, 2008; Albrecht, Vuuren and Vroman, 2009, Chamkhi and Toutlemonde, 2015), to the ethnic origin (Cédiey, Foroni and Garner, 2008) or a combination of both (Pailhé and ponthieux, 2008) and its empirical study is based on wages.

The methodology used to empirically measure discrimination can be classified in three groups (Couppié, Dupray and Moullet, 2009 and 2014): the declaratory or subjective approach to discrimination based on "felt discrimination" (Céreq, 2007), the experimental approach related to testing or control methods (Carlsson and Rooth, 2007; Cédiey, Foroni and Garner, 2008) and the econometric approach (Albrecht, Björklund and Vroman, 2003). The last approach is certainly the most advanced and most used. The approach used by this method to measure the gender wage gap consists in comparing the average wages of men and women, either by going from a non discriminatory structure of payment has led to the development of many alternatives (see Oaxaca and Ransom, 1994; Silber and Weber, 1999 respectively for a theoretical and empirical review), or by the aggregation of the theoretical non-discriminatory wages and the observed wages of individuals (Gardeazabal and Ugidos, 2005, Del Rio, Gradin and canto, 2006). The majority of these recent studies carried out in developed countries use a decomposition based on the use of quantiles in order to capture variations on the distribution of wages. Given the multiple hypotheses and methods used to measure discrimination, this study does a theoretical and empirical analysis of studies carried out in Africa in order to determine if, despite the much encouraged $^{1}$ professional equity, women are still victims of wage discrimination and consequently, if the "glass

The international labour organisation (ILO) in 1958 already indicated that «all individuals without discrimination should benefit from equality of chances and treatment when it comes to access to services». The UNO in its declaration on the 72 
ceiling" remains a reality. This study is organized in five sections. Section 2 does a theoretical review of the literature on the gender wage gap. Section 3 focuses on an empirical review which focuses on the main results. Section 4 presents the case of Cameroon given that Central Africa is not represented. Section 5 concludes the study.

\section{2 - The gender wage gap: theoretical evidence}

The theoretical analysis of the gender wage gap is based mainly on human capital theory and discrimination theories. The theory of the human capital explains differences in wages by differences in the productivity of individuals which themselves depend on their levels of investment in human capital (Becker, 1964). Expectations of women on their family responsibilities which will likely not give them the possibility of offering as many work hours as men makes them invest less than men. This difference in investment in human capital is at the origin of the wage gap between men and women (Mincer and Polachek, 1974). It is thus established that wage inequalities are explained by quantitative and qualitative differences in training in both the educational domain and the professional field of training. However, a given level of human capital will never have the same output in all the jobs occupied.

In developed and developing countries, the economic theories on discrimination focus on a commercial vision of labour which automatically excludes a possible market determination of wages. They thus seek to explain the part of the wage gap that is not explained by differences in the productivity of workers rather than the part that is due to their membership to a given group of individuals. In fact, when employers have predetermined ideas on a given group of individuals, recruiting the members of this group leads to a psychological cost which pushes these employers to retain the members of the other group by offering them higher wages. However, it is important to distinguish between the public and the private sector in terms of remuneration. Obviously, in the public sector, especially in Africa, competition between employees is absent, unlike in the private sector which cannot be completely freed from the influence of the job market. This last aspect logically leads to constraints that are likely to affect the choice of certain stakeholders when this is possible ${ }^{2}$. Women would clearly privilege the working conditions whereas men would attach more importance to career perspectives (England, 1992).

One of the forms of discrimination which is based on the beliefs of the employers, employees, and consumers is "discrimination by taste" (Becker, 1957; Arrow, 1973). We also talk about quartering models (Zellner, 1972) in the case where companies exclude women from certain better remunerated jobs qualified as "masculine" jobs.

The study by Phelps (1972) on "statistical discrimination" attributes the low remuneration of women to a lower visibility of the signals of their competences relative to those of men, thus, imperfections in information. It arises for example that for an equal level of education between men and women, the female career would be less favourable due to career interruptions they could face. In addition, on the basis of the fact that the valuation of their signals could be less, women invest less in human capital during their career. The consequence of this situation is their assignment to jobs that are unfavourable in terms of promotion (Lazear and Rosen, 1990). However, the pairing theory postulates that the employer improves his evaluation of the individual competences of men and women during the career, such that the most senior women are not discriminated against any more (Oettinger, 1996). The information on women thus appear less reliable at the beginning of the career, unlike those of men.

Most of the methods of decomposition of the gender wage gap developed since the eighties are based on the estimation of return functions and seek to identify the wage differential which results from the differences in the characteristics explained share, and the differential which comes from the fact that for a given level of characteristics, a man and a woman are not remunerated equally- unexplained share. This second share is interpreted as a "pure" measure of wage discrimination. The gender wage gap can be explained by various arguments which illustrate the different significant interpretations. In the neo-classical economic literature, wage discrimination is defined as the wage gap which can be explained by "objective" differences such as levels of education, type of occupation, the branch of industry, ...

The analyses of wage discrimination traditionally implemented in the literature are based on the decomposition the gender wage gap by Oaxaca (1973) and Blinder (1973). It is simply a question of separating the part of wages related to the differences in observable characteristics of the individuals to that not explained by these differences and is regarded

elimination of discrimination against women of the $7^{\text {th }}$ November 1967 stipulates in article 1 that «Discrimination against women is fundamentally unjust because it denies or limits equity between men and women and is against human dignity».

${ }^{2}$ In developing countries, the rate of unemployment is high to the point of not giving the chance to an individual of chosing between one sector and the other. 
as discrimination. However, these approaches do not take into account inequality of access to employment and the fact that, not only are women confined in less qualified, less remunerated and less protected jobs, all things being equal, they are less better paid than men. The application of quantile regressions to the estimation of wages and the returns to education was initiated by Buchinsky (1994) in the United States. Although the emphasis was laid on the wage gap between women, this study influenced studies on the gender wage gap, particularly the procedure of correction of selection bias. Following the seminal work of Buchinsky, this methodology was adopted by several authors. This is the case of Albrecht et al. (2003) who use quantile regressions and find that the differential of the logarithm of wage is high at the top of the distribution of wages in Sweden. Albrecht et al. (2004) also use the quantile regression based on the methods of decomposition of Machado and Mata (2001) to analyze the gender wage gap in the Netherlands. The result of the decomposition reveals that an important share of the wage gap is due to differences between the returns attributed to the job market rather than to differences in characteristics. This result mainly shows a strong discrimination against women.

Unlike the above studies which are based on the differences in the individual levels of education, others stratify their samples by groups of education. Such is the case of De la Rica et al., (2005) who find that discrimination is practiced for the most educated in Spain. The authors find that a less convincing argument acts at the top of the distribution and that women are less frequently promoted.

Also, in a comparative analysis, Arulampalam et al., (2004) use quantile regression to show that gender affects the distribution of wages in the public and private sectors of twelve European countries. Their results show a large wage gap at the top of the distribution of the wages in four countries (Denmark, Finland, Italy and Netherlands). The gender wage gap is large but equitably distributed at the bottom and top of the distribution in Australia, Belgium, Spain and France. However, unlike in the public sector, the private sector has a very large wage gap. Also, Kee (2005) analyzes wage gap in the public and private sector in Australia. This analysis reveals a large level of discrimination in the private sector and concludes that the wage gap observed in the two sectors is the result of differences in the returns by gender.

In developing countries in general and Africa in particular, Appleton et al., (1999) note that it is undeniable that the literature on gender is rather poor. However, some studies were undertaken on discrimination in the wage gap between men and women without using the techniques of quantile regressions (Ajwad and Kurukulasuriya, 2002, Hinks, 2002, Gruen, 2004). Certain studies, particularly the most recent however adopt the methodology of quantile regression (Nordman and Wolf, 2007 and 2008, Kandil, 2009). We thus present the methodologies and main results of some studies undertaken in Africa.

\section{3 - Overview of some econometric studies on the job market in Africa and main results}

Studies on the gender wage gap in Africa are rather numerous but to our knowledge, very few are recent. Existing studies focus on wage discrimination and the effects of glass ceilings i.e. the level of the gender wage gap and the absence of women in jobs located at the top of the hierarchy, despite an increase in their level of education. Among the studies we present in this article, we can chronologically cite: Appleton, Hoddinott and Krishnan (1999) for the case of the Ivory Coast, Ethiopia and Uganda, Nordman and Wolf (2007) for Morocco, Ntuli (2007) for South Africa, Nordman and Wolf (2008) for Madagascar and the Mauritius island, U. Agesa, J. Agesa and A. Dabalen (2008) for Kenya and Kandil (2009) for Egypt. This study focuses on all the sub-regions of the continent ${ }^{3}$, except Central Africa. For this reason and in order to include all regions, we analyze the gender wage gap in the Cameroonian public and private sectors.

\section{1 - Traditional methodology}

Generally, the methods of decomposition of the gender wage gap used by these authors go from the estimation of earning equations establishing a relationship between the logarithm of wages and explanatory variables ${ }^{4}$.

Following the example Albrecht et al. (2003), the decomposition of the wage gap which exists between two groups of individuals requires capturing the differences between the characteristics of the two groups and the part of the wage differential explained by differences in the valuation of these characteristics. Thus, if all the relevant characteristics were taken into account and the structures of the two populations were identical for the set of the variables considered,

\footnotetext{
${ }^{3}$ South Africa for Southern Africa; Ethiopia, Kenya, Madagascar, Mauritius island and Uganda for East Africa ; Morocco and Egypt for North Africa; the Ivory Coast for West Africa.

${ }^{4}$ For more information on the wage and explanatory variables, see table 1.
} 
any wage differences would result only from differences in the productivity of these characteristics. However, if the returns are similar, the wage gap is considered to come from structural effects in the various forms of segregation.

The majority of studies presented ${ }^{5}$ seek to determine the gender wage gap on all the distribution and adopts the method of quantile regression in Koenker and Basset (1978) and Buchinsky (1998). The method of quantile regression makes it possible to measure the effect of an individual characteristic on the logarithm of wages in different points of the distribution of wages. The model is defined such follows:

$Q_{\theta}(\ln Y)=\alpha_{\theta} X$, avec $\left.\theta \epsilon\right] 0,1[$

where $Q_{\theta}(\ln Y)$ represents the quantile of order $\theta$ of wages whose individual characteristics are $X, \alpha_{\theta}$ is the vector of parameters. The estimation for low values of $\theta$ i.e. close to 0 concerns the least remunerated whereas the values of $\theta$ close to 1 represent the highest wages.

Generally, the estimation of the parameters is done by solving the following equation:

$$
\min _{\alpha_{\theta}}\left(\sum_{i: \ln (Y) \geq X_{i} \alpha_{\theta}} \theta\left|\ln \left(Y_{i}\right)-X_{i} \alpha_{\theta}\right|+\sum_{i: \ln (Y)<X_{i} \alpha_{\theta}}(1-\theta)\left|\ln \left(Y_{i}\right)-X_{i} \alpha_{\theta}\right|\right)
$$

The solution of this equation is obtained by the linear programming algorithm.

The method of decomposition suggested by Machado and Mata (2005) which corresponds to an extension of that Oaxaca-Blinder (1973) is applied in the case of quantile regressions. It consists in generating the marginal densities and the counterfactual densities of the dependent variable (the logarithm of the hourly or monthly wage).

Within a group, four successive stages enable us to generate the marginal densities of the logarithm of wages for women and men given the respective individual and employment characteristics.

- Randomly generate a sample of size $n$ following a uniform distribution in the interval [0,1]: $\theta_{1}, \theta_{2}, \theta_{3}, \ldots, \theta_{n}$

- In each group, estimate for each percentile $I=1,2, \ldots, n$ the vector $Q_{\theta}(\ln Y \mid X)$ of regression coefficients of the quantile regression. We obtain $n$ vectors of coefficients.

- In the various quantiles $\theta_{i}$ of each group, we draw in a random manner and replacement $n$ individuals. We thus obtain for each group n sub-samples written $\left\{X_{i}^{*}\right\}, I=1,2, \ldots, N$.

- We then predict for each group and in each quantile $\theta_{i}$ the expression $\left\{\ln Y_{i}^{*} \equiv X_{i}^{*} \hat{\alpha}\left(\theta_{i}\right)\right\}_{i=1}^{n}$ to obtain the distribution of the conditional wages, given the employment and individual characteristics for men and women making it possible to calculate the density function. There are thus the marginal densities of men and women.

In order to decompose the gender wage gap, we generate the counterfactual densities by supposing on the one hand that men and women are equally remunerated, and on the other hand, that women are remunerated as men, given the respective individual characteristics. The estimation is done on the basis of the above four stages. Also we can generate the counterfactual gap that leads to the share explained by the individual characteristics and an unexplained share by the aforementioned characteristics.

\section{2 - Estimates and main results}

The studies presented in this article are all of from the field of applied microeconomics and are summarized in the table below:

\footnotetext{
${ }^{5}$ Except U. Agesa, J. Agesa and A. Dabalen (2008) who use a different decomposition principle.
} 


\begin{tabular}{|c|c|c|c|c|c|c|}
\hline $\begin{array}{l}\text { Authors and titles of } \\
\text { articles }\end{array}$ & $\begin{array}{l}\text { S.Appletton, J. } \\
\text { Hoddinott and P } \\
\text { Krishnan, } \\
\text { "The Gender Wage Gap in Three African } \\
\text { Countries", Economic Development and } \\
\text { Cultural Change, } 47(2), 1999 .\end{array}$ & $\begin{array}{l}\text { C. J. Nordman and F.-C. Wolff, "Is there a } \\
\text { glass ceiling in Morocco? Evidence from } \\
\text { matched workers-firm data", DIAL } \\
\text { Document de Travail DT/2007-04, 2007. }\end{array}$ & $\begin{array}{l}\text { M. Ntuli, "Exploring Gender Wage } \\
\text { Discrimination in South Africa, 1995- } \\
\text { 2004: A Quantile Regression Approach", } \\
\text { International Policy Center Working } \\
\text { Paper Series Number 56, 2007. }\end{array}$ & $\begin{array}{l}\text { C. J. Nordman et F.-C. Wolff, "Islands } \\
\text { through the glass ceiling? Evidence of } \\
\text { gender wage gaps in Madagascar and } \\
\text { Mauritius", DIAL Document de Travail } \\
\text { DT/2008-02, 2008. }\end{array}$ & $\begin{array}{l}\text { R. U. Agesa, J. Agesa et A. Dabalen, } \\
\text { "Changes in Wage Distributions, Wage } \\
\text { Gaps and Wage Inequality by Gender } \\
\text { in Kenya", Journal of African } \\
\text { Economies, vol. 18, n } 3,2008 \text {. }\end{array}$ & $\begin{array}{l}\text { L. E. Kandil, "Gender } \\
\text { Discrimination in Egypt : A Quantile } \\
\text { Regression Analysis", 26th Applied } \\
\text { Microeconomics days, Dijon, } 4 \text { and } 5 \\
\text { june, 2009 }\end{array}$ \\
\hline Source & $\begin{array}{l}\text { - Survey on fertility, reproduction } \\
\text { behaviour, and the employment status of } \\
\text { urban youths in Ethiopia (1990); } \\
\text { - Survey on the living standards in the } \\
\text { Ivory Coast (1985, 1986 and 1987); } \\
\text { - Uganda Intergrated survey (1992). }\end{array}$ & $\begin{array}{l}\text { Firm Analysis and Competitiveness } \\
\text { Survey (FACS) organised by the Ministry } \\
\text { of trade and industry since } 1985 \text { for the } \\
\text { analysis of data on manufacturing } \\
\text { companies. }\end{array}$ & $\begin{array}{l}\text { Labour Force Survey (LFS_2 -bi-annual } \\
\text { survey), September } 2004 \text { and October } \\
\text { Household Surveys (OHS - annual } \\
\text { survey), } 1995 \text { and } 1999 \text {. Surveys carried } \\
\text { out by Statistics South Africa (Stats SA). }\end{array}$ & $\begin{array}{l}\text { Survey done by the World bank in } 2005 \\
\text { within the framework of the African } \\
\text { regional programme for enterprise } \\
\text { development (ARPED) The evaluation of } \\
\text { the investment climate (ICA) }\end{array}$ & $\begin{array}{l}\text { Three data sources: } \\
\text { - 1977 Labor Force Survey (1977 } \\
\text { LFS), } \\
\text { - 1986 Labor Force Survey (1986 } \\
\text { LFS), } \\
\text { - 1999 Labor Force Survey (1999 LFS) }\end{array}$ & $\begin{array}{l}\text { Three databases: } \\
\text { - The Egyptian Labour Market Survey } \\
\text { (ELMS) of } 1988 \text { and } 1998 ; \\
\text { - The Egyptian Labour Market Panel } \\
\text { Survey (ELMPS) of } 2006 .\end{array}$ \\
\hline Study population & $\begin{array}{l}\text { Urban workers aged between } 15 \text { and } 59 \\
\text { years in the Ivory Coast and Uganda, 15- } \\
30 \text { years in Ethiopia. } 1985 \text { sample ( } 733 \\
\text { men and } 1252 \text { women), } 5767 \text { ( } 2551 \text { men } \\
\text { and } 3216 \text { women) and } 6250 \text { (2869 men } \\
\text { and } 3381 \text { women) respectively for } \\
\text { Ethiopia, the Ivory Coast and Uganda. }\end{array}$ & $\begin{array}{l}\text { Matched } \\
\text { employer-employee data including more } \\
\text { than } 8000 \text { workers from } 850 \\
\text { manufacturing companies collected } \\
\text { between october } 2000 \text { and february } 2001 .\end{array}$ & $\begin{array}{l}\text { Identification of } 3000 \text { sectors for } \\
\text { interviews with } 10 \text { households per sector, } \\
\text { giving a sample of } 30000 \text { households. } \\
\text { The individuals are aged between } 15 \text { and } \\
65 \text { years and are workers and } \\
\text { unemployed, of which } 68000 \text { are workers. }\end{array}$ & $\begin{array}{l}\text { Matched employer-employee data of } 198 \\
\text { and } 290 \text { enterprises chosen at random for } \\
\text { the Mauritius islands and Madagascar } \\
\text { respectively based on stratification by } \\
\text { sector, size and localisation. The samples } \\
\text { have } 1363 \text { and } 1734 \text { employees } \\
\text { respectively. }\end{array}$ & $\begin{array}{l}\text { - } 1977 \text { LFS relating to the urban and } \\
\text { rural components and includes } 1611 \\
\text { men and } 340 \text { women. } \\
-1986 \text { LFS also relating to urban and } \\
\text { rural components and includes } 1949 \\
\text { men and } 629 \text { women. } \\
-1999 \text { LFS relates to the three } \\
\text { modules labour, informal sector and } \\
\text { child labour. The first two components } \\
\text { enable us to select a sub-sample of } \\
3303 \text { men and } 1153 \text { women. }\end{array}$ & $\begin{array}{l}\text { Sample of workers of the formal sector } \\
\text { having completed their studies and aged } \\
\text { between } 16 \text { and } 65 \text { years. This gives } 4199 \\
(3120 \text { men and } 1079 \text { women), } 2761(1955 \\
\text { men and } 806 \text { women) and } 1814 \text { (1249 } \\
\text { men and } 565 \text { women) workers, } \\
\text { respectively in 2006, } 1998 \text { and } 1988 .\end{array}$ \\
\hline Dependent variable & Monthly wage & Monthly wage & Monthly wage & Hourly wage & Hourly wage & Hourly wage \\
\hline $\begin{array}{l}\text { Selected independent } \\
\text { variables used in the } \\
\text { wage equation }\end{array}$ & $\begin{array}{l}\text { Potential experience, education, marital } \\
\text { status, sectors of activity (public and } \\
\text { private), nationality (for the Ivory Coast). }\end{array}$ & $\begin{array}{l}\text { Number of years of education completed, } \\
\text { Number of children, potential experience, } \\
\text { seniority, number of former jobs, formal } \\
\text { training during previous job, number of } \\
\text { years of unemployment between the two } \\
\text { previous jobs. }\end{array}$ & $\begin{array}{l}\text { Âge, number of working hours, marital } \\
\text { status, level of education (primary, } \\
\text { secondary, higher, PhD.), occupation } \\
\text { (manager, professional, technician, Office } \\
\text { staff, trained employee, farmer, craftsman, } \\
\text { elementary jobs), sector of activity, } \\
\text { province. }\end{array}$ & $\begin{array}{l}\text { Marital status, number of years of } \\
\text { education completed, seniority in the } \\
\text { company, seniority in the firm. }\end{array}$ & $\begin{array}{l}\text { Seniority, Education (primary, } \\
\text { secondary, higher) and the } 8 \text { regions. }\end{array}$ & $\begin{array}{l}\text { Potential experience, Potential experience } \\
\text { relative to the number of children in the } \\
\text { household, seniority in the company, } \\
\text { education (six levels), Marital status, } \\
\text { number of children in the household, } \\
\text { sector of activity, member of trade union, } \\
\text { region, distance of home from job site. }\end{array}$ \\
\hline Type of décomposition & $\begin{array}{l}\text { - Oaxaca (1973) } \\
\text { - Neumark (1988) }\end{array}$ & $\begin{array}{l}\text { - Oaxaca-Blinder (1973) } \\
\text { - Machado-Mata (2005) }\end{array}$ & - Machado-Mata (2005) & $\begin{array}{l}\text { - Oaxaca-Blinder (1973) using ordinary } \\
\text { least squares and fixed effects regression } \\
\text { - Machado-Mata (2005) with and without } \\
\text { professional segregation in the companies. }\end{array}$ & $\begin{array}{l}\text { - Complete decomposition of wages } \\
\text { implemented by Lemieux (2002). }\end{array}$ & - Machado-Mata (2005) \\
\hline Results & $\begin{array}{l}\text { Wage gap is small in the Ivory Coast but } \\
\text { substantial in Ethiopia and Uganda } \\
\text { (because of the returns to the } \\
\text { characteristics of workers). However, the } \\
\text { wage gap is moderate in the three } \\
\text { countries because of the over- } \\
\text { representation of women in the highest } \\
\text { wages of the public sector. } \\
\text { According to the authors, these results } \\
\text { could have been different if conventional } \\
\text { decomposition methods had been used. }\end{array}$ & $\begin{array}{l}\text { Gender wage gap is higher at the top of } \\
\text { the wage distribution than at the bottom. } \\
\text { The gender wage gap increases at the top } \\
\text { of the distribution when the specific } \\
\text { characteristics of the companies are } \\
\text { controlled for. } \\
\text { Glass ceiling effect that can become } \\
\text { stronger with time in these companies } \\
\text { given that men with high wages benefit } \\
\text { from a higher growth in wages relative to } \\
\text { their female colleagues. }\end{array}$ & $\begin{array}{l}\text { Increase in the gender wage gap from } \\
1995 \text { to } 2004 \text { while almost } 10 \text { years after } \\
\text { the end of apartheid, a a fall in this gap was } \\
\text { expected. Existence of a lower limit in the } \\
\text { South African job market. Women are } \\
\text { increasingly discriminated against despite } \\
\text { the existence of a labour code that } \\
\text { promotes equality between genders. }\end{array}$ & $\begin{array}{l}\text { Low gender wage gap adjusted for } \\
\text { individual characteristics in Madagascar } \\
\text { but relatively high in the Mauritius } \\
\text { islands. There is thus a high level of } \\
\text { heterogeneity in the two countries. } \\
\text { Existence of enterprises paying low wages } \\
\text { to women and high wages to men but no } \\
\text { glass ceiling exists in the two countries. }\end{array}$ & $\begin{array}{l}\text { The marginal returns, (mesured or not) } \\
\text { to humancapital is relatively high for } \\
\text { men and is highly dispersed wage } \\
\text { residual which is a direct consequence. } \\
\text { Despite the increase in the level of } \\
\text { education of women, the marginal } \\
\text { returns to human capital for men is } \\
\text { proof of a persistent discrimination } \\
\text { against women in Sub-Saharan Africa } \\
\text { in general and Kenya in particular. }\end{array}$ & $\begin{array}{l}\text { Existence of a gender wage gap that } \\
\text { increases with the percentile of the } \\
\text { distribution, showing a glass ceiling. This } \\
\text { result holds for all three years although } \\
\text { there is a relative fall in the intensity of } \\
\text { discrimination between } 1998 \text { and } 2006 \text {. }\end{array}$ \\
\hline
\end{tabular}




\section{4 - Analysis of the gender wage gap in Cameroon}

Recent econometric studies on the gender wage gap uses cross sectional observations and consider the observable characteristics of individuals as exogenous data. This data cannot therefore be affected by discriminatory behaviour. Discrimination as portrayed in this case thus differs from that of Becker (1957) since the decomposition of the gender wage gap simply makes it possible to answer the question: given the same characteristics and the same job, are men and women given identical wages? The levels of wages and characteristics of individuals enable us to answer, at least partially, this question in the case of Cameroon.

\section{1 - Earnings function and the principle of decomposition of the wage gap}

The empirical analysis of the decomposition of the wage gap is based on the estimation of Mincer (1974) type earnings equations of the form:

$$
\ln Y_{i}=\beta X_{i}+\mu_{i}
$$

Where $\ln Y_{i}$ corresponds to the logarithm of the monthly wage of individual $i, X_{i}$ is the set of variables showing the individual characteristics of the workers, $\beta$ is the vector of the estimated coefficients of the variables and $\mu_{i}$ the residuals with zero mean and standard deviation $\sigma$. The following variables are introduced as explanatory variables: professional experience, seniority, time worked (in hours), level of education certified by the diploma, the branch of industry, the area of residence, the number of children and matrimonial status.

The recruitment process remains a recurring problem in the estimation of earnings functions given endogeneity and the phenomenon of unobserved heterogeneity which causes bias. In fact, the dependant variable $\left(Y_{i}\right)$ being observed only for a non random part of the total population, the correction of selection bias is essential in the study of gender wage gaps. To correct this bias, we use the common Heckman (1979) two stage method which consists in rendering the conditional expectation of the residual equal to zero by introducing the earnings equation an estimator of the selection term. This selection term, under the assumption of normality of the error term is proportional to the inverse of the Mills ratio given by the ratio between the density function and cumulative density function.

Following Oaxaca (1973), Blinder (1973) and Oaxaca and Ransom (1994), we can formulate the following decomposition whose goal is to identify the sources of the differences between the average earnings of men and women.

Given $\ln Y^{H}$ and $\ln Y^{F}$ the logarithms of the monthly wages of men and women respectively, defined such that $\ln Y^{H}=\beta X^{H}+\mu^{H}$ and $\ln Y^{F}=\beta X^{F}+\mu^{F}$ are the earnings equations of men and women in the sample. We can write:

$$
\ln Y^{H}-\ln Y^{F}=\beta^{H}\left(X^{H}-X^{F}\right)+\left(\beta^{H}-\beta^{F}\right) X^{F}
$$

where $\beta^{H}$ and $\beta^{F}$ are the returns of the characteristics estimated in the earnings equations of men and women respectively. $\beta^{H}\left(X^{H}-X^{F}\right)$ represents the variation explained by the difference in characteristics between men and women valued by the earnings of men - explained share; $\left(\beta^{H}-\beta^{F}\right) X^{F}$ corresponds to the difference between the earnings of the characteristics for men and women estimated with the average characteristics of women - unexplained share. Equation (4) is such that if the structure of men was similar to that of women for the variables considered (education, professional experience,...), any wage gap is the result of a difference in the earnings of these characteristics (pure discrimination). But, if the earnings were equal, the difference in average wages is entirely explained by structural effects which originate from other types of discriminations (access to education, accumulation of experience,...).

In order to capture the wage gap on all the distribution, we do a quantile analysis. This analysis unlike ordinary least squares, enables us to decide on wage gaps at many levels of the distribution of wages.

\section{2 - Data used and some descriptive statistics}

The data used in this study come from the second Employment and Informal sector survey (EESI) carried out by the National institute of Statistics of Cameroon (INS) in 2010. This survey provides much information on the public and 
private sectors. We extract a sample of 2372 individuals aged between 20 and 65 years of which 843 and 954 were men and 364 and 211 were women in the public and private sector respectively. These figures show that the market is mainly dominated by male workers. In the public sector, $69,84 \%$ are men against 30,16\% women while the formal private sector $81,89 \%$ are men against $18,11 \%$ women.

The gender wage gap is shown in the table below

Table 2: monthly wage gap between men and women

\begin{tabular}{lcccc}
\hline & Men $(\mathrm{H})$ & Women $(\mathrm{F})$ & {$[(\mathrm{H})-(\mathrm{F})] /(\mathrm{F})$ in \% } & Global \\
\hline Public sector & & & & \\
Average monthly salary & 141585,2 & 119925,5 & 18,06 & 134995,4 \\
Median wages & 131216,3 & 120000 & 9,34 & 128026,6 \\
D1 & 31000 & 30000 & 3,33 & 30000 \\
D9 & 256012,7 & 245839,4 & 4,13 & 253407,4 \\
D9/D1 & 8,15 & 8,19 & - & - \\
Private sector & & & & \\
Average monthly salary & 115418,6 & 104928,8 & 9,99 & 113469,3 \\
Median wages & 65230,02 & 62262,72 & 4,77 & 64958,51 \\
D1 & 26.000 & 20.000 & 30,00 & 25.000 \\
D9 & 252684,2 & 246209,8 & 2,62 & 252464,5 \\
D9/D1 & 9,718 & 12,310 & - & - \\
\hline Source: & & &
\end{tabular}

Source: INS, EESI2 - 2010

These results show that the gender wage gap is favourable to men. Against all expectations, this wage gap is greater in the public sector. We also find that the guaranteed minimum wage (SMIC) does not play any part in setting a floor wage in the private sector given that in the first percentile, women have wages lower than CFAF $23500^{6}$.

\section{3 - Estimation results}

The results in table 3 show a negative and significant coefficient attached to the variable female sex for both the public and private sectors. In the public sector, on average, the wages perceived by women are $15,7 \%$ lower than those of men. In the private sector on the other hand, they are $10,2 \%$ lower than those of men, that is to say a lower percentage than that of the public sector. This result is contrary to our expectations since in the public sector; men and women are subjected to the same salary grid and same advancement conditions. This difference possibly comes from advantages related to promotion and nomination at positions of responsibility which favour men. However, these variations show that women are victims of significantly discrimination in the two sectors, even if the levels are different. This result is however surprising especially if we admit the hypothesis according to which the "signals" of women are less perceptible than those of men (Phelps, 1972). In fact, recruitment in the public sector being done by way of competition, the validity of such a hypothesis is excluded during recruitment.

The returns of all the levels of education are significant, positive and increasing with the diploma in the two sectors ${ }^{7}$. It is also important to notice that for increasingly high diplomas (MAITRISE/DEA/MBA and DOCTORAT/PHD), the returns to education are higher in the private sector than in the public sector. Compared to the rural environment, the earnings of the urban and semi-urban environments are all positive but the urban environment contributes more to the explanation of wages, particularly in the private sector.

Table 3: Earnings function of the public and private sectors

\begin{tabular}{lcc}
\hline Variables & Public sector & Private sector \\
\hline Constant & $4,759 * * *$ & $4,202 * * *$ \\
& $(0,232)$ & $(0,255)$ \\
Female sex & $-0,157 * * *$ & $-0,102 *$
\end{tabular}

\footnotetext{
${ }^{6}$ The value of the minimum wage (SMIC) during the survey. However, decree $\mathrm{N}^{\circ}$ 2014/2217/PM of the 24th july 2014 increases the SMIC to CFAF36.270.
}

${ }^{7}$ Except for CEPE/FSLC whose earnings are positive but non significant 


\begin{tabular}{|c|c|c|}
\hline \multirow{3}{*}{ Experience } & $(0036)$ & $(0,052)$ \\
\hline & $0,053 * * *$ & $0,80 * * *$ \\
\hline & $(0,010)$ & $(0,017)$ \\
\hline Experience $^{2}$ & $-0,001 * * *$ & $-0,001 * *$ \\
\hline Seniority & $\begin{array}{c}(0,0003) \\
-0,018 \\
(0,011)\end{array}$ & $\begin{array}{c}(0,0005) \\
-0,019 \\
(0,018)\end{array}$ \\
\hline Seniority $^{2}$ & $\begin{array}{l}(0,011) \\
0,00003 \\
(0,0004)\end{array}$ & $\begin{array}{c}(0,018) \\
-0,0002 \\
(0,0006)\end{array}$ \\
\hline Number of hours worked & $\begin{array}{c}0,002 * * * \\
(0,0005)\end{array}$ & $\begin{array}{c}0,0002 \\
(0,0003)\end{array}$ \\
\hline \multicolumn{3}{|l|}{ Education (Diploma) } \\
\hline Without diploma (ref.) & - & - \\
\hline CEPE/FSLC & $\begin{array}{c}0,455 * * * \\
(0,090)\end{array}$ & $\begin{array}{c}0,068 \\
(0,069)\end{array}$ \\
\hline BEPC/CAP/GCEOL & $\begin{array}{c}0,747 \text { *** } \\
(0,091)\end{array}$ & $\begin{array}{c}0,377 \text { *** } \\
(0,074)\end{array}$ \\
\hline PROBATOIRE & $\begin{array}{c}0,663 * * * \\
(0,102)\end{array}$ & $\begin{array}{c}0,564 * * * \\
(0,099)\end{array}$ \\
\hline BACC/GCEAL/BEP & $\begin{array}{c}0,870 \text { *** } \\
(0,090)\end{array}$ & $\begin{array}{c}0,711 \text { *** } \\
(0,081)\end{array}$ \\
\hline BTS/DUT/DEUG & $\begin{array}{c}1,204 * * * \\
(0,115)\end{array}$ & $\begin{array}{c}1,085 * * * \\
(0,112)\end{array}$ \\
\hline LICENSE/BACHELORS & $\begin{array}{c}1,196 * * * \\
(0,098)\end{array}$ & $\begin{array}{c}1,060 \text { *** } \\
(0,101)\end{array}$ \\
\hline MAITRISE/DEA/MBA & $\begin{array}{c}1,315 * * * \\
(0,100)\end{array}$ & $\begin{array}{c}1,497 * * * \\
(0,103)\end{array}$ \\
\hline DOCTORAT/PHD & $\begin{array}{c}1,372 * * * \\
(0,141)\end{array}$ & $\begin{array}{c}1,976 * * * \\
(0,210)\end{array}$ \\
\hline \\
\hline Primary sector (ref.) & - & - \\
\hline Industrial sector & $\begin{array}{c}0,123 \\
(0,148)\end{array}$ & $\begin{array}{c}0,140 \\
(0,086)\end{array}$ \\
\hline Tertiary sector & $\begin{array}{c}0,057 \\
(0,131)\end{array}$ & $\begin{array}{l}-0,056 \\
(0,085)\end{array}$ \\
\hline \multicolumn{3}{|l|}{ Area of residence } \\
\hline Rural (ref.) & - & - \\
\hline Urban environment & $\begin{array}{c}0,166 * * * \\
(0,063)\end{array}$ & $\begin{array}{c}0,134 \\
(0,093)\end{array}$ \\
\hline Semi-urban area & $\begin{array}{c}0,146 * * \\
(0,068)\end{array}$ & $\begin{array}{c}0,037 \\
(0,098)\end{array}$ \\
\hline \multicolumn{3}{|l|}{ Number of children } \\
\hline Without child (ref.) & - & - \\
\hline 1 to 5 children & $\begin{array}{c}-0,085 * * \\
(0,042)\end{array}$ & $\begin{array}{c}0,001 \\
(0,045)\end{array}$ \\
\hline More than 5 children & $\begin{array}{c}0,034 \\
(0,059)\end{array}$ & $\begin{array}{l}-0,006 \\
(0,082)\end{array}$ \\
\hline \multicolumn{3}{|l|}{ Marital status } \\
\hline Single (ref.) & - & - \\
\hline Married & $\begin{array}{c}0,186 \text { *** } \\
(0,039)\end{array}$ & $\begin{array}{c}0,208 \text { *** } \\
(0,044)\end{array}$ \\
\hline Lambda & $\begin{array}{c}-1,043 \\
(0,059) \\
1207\end{array}$ & $\begin{array}{c}-0,518 \\
(0,083) \\
1165\end{array}$ \\
\hline
\end{tabular}

Dependant variable: logarithm of the monthly wage

The standard deviations appear in brackets. The levels of significance are respectively: $1 \%(* * *), 5 \%(* *)$ and $10 \%(*)$. Source: INS, EESI2 - 2010

In view of better explaining the effect of the characteristics of the workers on their wages, we chose to consider the estimation of the wage equation by quantiles. In fact, a global approach has an important limit which is the consideration of an average wage gap whatever the level of wages.

The examination of quantile regression by gender reveals differences in the remuneration of observable characteristics. But in order to better determine the wage differences between men and women, it is important to dissociate the share 
related to the individual characteristics from that which is free from these characteristics. Table 4 provides these differences according to the percentiles.

Table 4: Decomposition of the gender wage gap in the public and private sectors

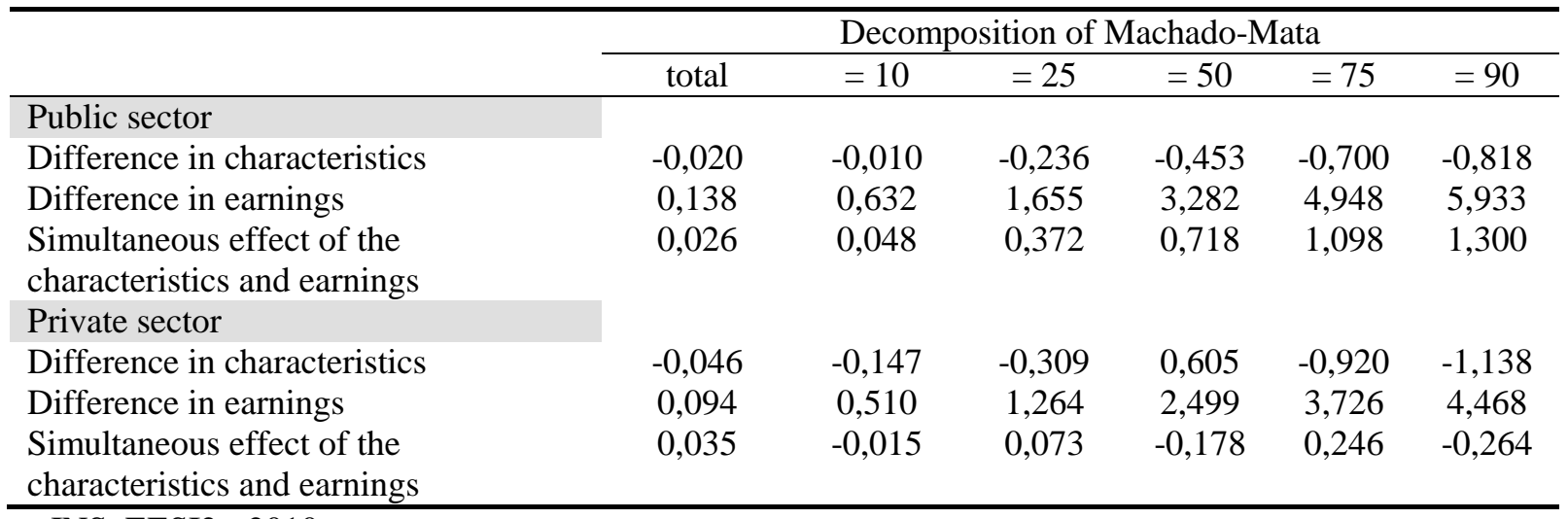

Source: INS, EESI2 - 2010

Globally, as shown in the different percentiles, the earnings gap is largely greater than the difference in the characteristics in the two sectors. Being a woman thus leads to a wage penalty in the public and private sectors. This penalty which increases with the percentile is higher in the public sector. This increase shows the existence of a "glass ceiling effect" in the two sectors.

Although women find themselves at all wage levels, they are victims of discrimination throughout the distribution but this is more in the public sector than in the private sector.

\section{5 - Conclusion}

At the theoretical and practical levels, companies and public services have gone beyond the point of predetermined mindsets on the qualifications of women. Women undergo the same training like men but discrimination, although effective in many domains, is far from being stereotyped. Most of the econometric studies presented in this study conclude that women earn lower wages relative to men, proof that they are victims of wage discrimination. Social traditions exert a great influence on the female labour. In fact, even if wage gaps are present in all sub-regions, they are most noticeable in North Africa. Moreover, it arises from the world employment trend that unlike what occurs in subSaharan Africa, the main difficulties encountered by women in North Africa in job markets are less from the bad quality jobs than the lack of access to the job markets. For the women of this region, female jobs are more of an exception than the rule. The wage gap reveals a glass ceiling effect that is perceptible in Morocco (Nordman and Wolf, 2007) and Egypt (Kandil, 2009). However, within the framework of sub-Saharan Africa, wage gaps in favour of men are also visible and far from being negligible. Although female employment has become prominent, inequality in terms of responsibilities persist in certain countries.

A comparative analysis of the main results shows that there exists a strong heterogeneity on the situation of women in the job market in Africa but it is difficult, contrary to what is considered by certain authors (Nordman and Wolf, 2008), to associate the gender wage differentials to the level of economic development of the different countries.

\section{References}

Agesa, R. U., Agesa, J. \& Dabalen, A. (2008), "Changes in Wage Distributions, Wage Gaps and Wage Inequality by Gender in Kenya", Journal of African Economies, vol. 18, n 3, pp. 431-460.

Ajwad, M. I. \& Kurukulasuriya (2002), "Ethnic and Gender Wage disparities in Sri Lanka", World Bank Research Working Paper, $\mathrm{N}^{\circ} 2859$.

Albrecht, J., Björklund, A. \& Vroman, S. (2003), "Is there a glass ceiling in Sweden ?", Journal of Labour Economics, vol. 21, pp. 145-177.

Albrecht, J., Vuuren, A. V. \& Vroman, S. (2004), "Decomposing the gender wage gap in the Netherlands with sample selection adjustments", IZA Discussion Paper, $\mathrm{N}^{\circ} 1400$.

Albrecht, J., Vuuren, A. V. \& Vroman, S. (2009), "Counterfactual distributions with sample selection adjustements : Econometric theory and an application to the Netherlands", Labour Economics, 16, pp. 383-396. 
Appleton, S., Hoddinott, J. \& Krishnan, P. (1999), "The Gender Wage Gap in Three African Countries", Economic Development and Cultural Change, Vol. 47, No. 2, pp. 289-312.

Antecol, H., Jong, A. \& Steinberger, M. (2008), "The sexual orientation wage gap : the role of occupationnal sorting and human capital", Industrial and Labour Relations Review, vol. 61, n 4, pp. 518-543.

Arrow, K. (1973), "The Theory of discrimination", dans Ashenfelter, O. et Rees, A. (éds), Discrimination in Labor Markets, Princeton University Press, p. 3-33.

Arulampalam, W., Booth, A. L. \& Bryan, M. L. (2004), "Is there a glass ceiling over Europe ? Exploring the gender pay gap across the wages distribution", IZA Discussion Paper, $\mathrm{n}^{\circ} 1373$.

Becker, G. S. (1957), The Economics of Discrimination, University of Chicago Press.

Becker, G. S. (1964), Human Capital, New York : Columbia University Press.

Blinder, A. S. (1973), "Wage discrimination: Reduced form and Structural variables", Journal of Human Resources, 8 , pp. 436-455.

Buchinsky, M. (1994), "Changes in the US Wage Structure 1963-1987: An application of Quantile Regression", Econometrica, vol. 62, pp. 405-58

Buchinsky, M. (1998), "The Dynamics of Changes in the Female Wage Distribution in the USA: A Quantile Regression Approach", Journal of Applied Econometrics, vol. 13, pp. 1-30.

Carlsson, M. \& Rooth, D. (2008), "Evidence of ethnic discrimination in the swedish labor market using experimental data", Labour Economics, vol. 14, n 4, pp 716-729.

Cédiey, E., Foroni, F. \& Garner, H. (2008), "Discriminations à l'embauche fondées sur l'origine à l'encontre de jeunes français(es) peu qualifié(e)s", Dares Premières synthèses, février, $\mathrm{n}^{\circ} 06.3$.

Céreq (Centre d'Etudes et de Recherches sur la Qualification), (2007), "Quand la carrière commence ... Les sept premières années de vie active de la génération 98".

Chamkhi, A. \& TouTLemonde, F. (2015), « Ségrégation professionnelle et écarts de salaires femmes-hommes », Dares Analyses, no 082.

Couppié, T., Dupray, A. \& Moullet, S. (2014), "Education-Based Occupational Segregation and the Gender Wage Gap: Evidence from France", International Journal of Manpower, vol. 35, no 3, pp. 368-391.

Couppié, T., Dupray, A. \& Moullet, S. (2009), "La mesure de la discrimination salariale revisitée : une tentative d'identification des femmes « véritablement » discriminées en début de vie active", Communication aux 4èmes rencontres Jeunes et sociétés en Europe et autour de la Méditerranée - Forli, Italie, 26-28 mars.

De la Rica, S., Dolado, J. J. \& Llorens, S. (2008), "Ceiling and floors: Gender wage gaps by education in Spain", Journal of Population Economics, vol. 21 (3), pp. 751-776. Del Rio, C., Gradin, C. \& canto, O. (2006), "The measurement of gender wage discrimination: the distributional approach revisited", ECINEQ Working Paper, 25.

England, P. (1992), Comparable Worth: Theories and Evidence, New York: Aldine De Gruyter.

Gardeazabal, J. \& Ugidos, A. (2005), "Gender wage discrimination at quantiles", Journal of Human Resources, vol. 18, pp. 165-179. Gruen, C. (2004), "Direct and Indirect Gender Wage Discrimination in the South Africa labour market", International Journal of Manpower, vol. 25, Nos 3-4, pp. 321-342. Heckman, J. (1979), "Sample Selection Bias as a Specification Error", Econometrica, vol. 47, n 1, pp. 153-161.

Hinks, T. (2002), "Gender Wage differentials and Discrimination in the new South Africa", Applied Economics, vol. 34(16), pp. 2043-205.

Kandil, L. E. (2009), "Gender Wage Discrimination in Egypt: A quantile Regression Analysis", 26ème Journée de Microéconomie Appliquée, Dijon, 4 et 5 juin, 46p.

Kee, H. J. (2005), "Glass ceiling or sticky floor? Exploring the Australian gender gap pay using quantile regression and counterfactual decomposition methods", The Australian National Discussion Paper, $\mathrm{N}^{\circ}$ 487.Koenker, R. \& Bassett, G. (1978), "Regression quantile", Econometrica, vol. 46, pp. 33-50.

Lazear, E. \& Rosen, S. (1990), "Male-Female Wage Differentials in Jobs Ladders", Journal of Labor Economics, vol. $8, \mathrm{n}^{\circ} 1$, pp. S106-S123.

Machado, J. A. \& Mata, J. (2001), "Earnings functions in Portugal 1982-1994: Evidence from quantile Regression", Empirical Economics, vol. 26, pp. 115-134.

Machado, J. A. \& Mata, J. (2005), "Counterfactual decomposition of changes in wage distributions using quantile regression", Journal of Applied Econometrics, vol. 20(4),pp. 445-465.

Mincer, J. (1974), Schooling, Experience, and Earnings, New York: National Bureau of Economic Research, Columbia University Press.

Mincer, J. \& Polachek, S. (1974), Family Investments in Human Capital: Earnings of Women, Journal of Political Economy, vol. 82, $\mathrm{n}^{\circ}$ 2, Part 2, pp. S76-S108. 
Nordman, C. J. \& Wolff, F.-C. (2007), "Is there a glass ceiling in Morocco? Evidence from matched workers-firm data", DIAL Document de Travail DT/2007-04.

Nordman, C. J. \& Wolff, F.-C. (2008), "Islands through the glass ceiling? Evidence of Gender wage gaps in Madagascar and Mauritius", DIAL Document de Travail DT/2008-02.

Ntuli, M. (2007), "Exploring Gender Wage Discrimination in South Africa, 1995-2004: A Quantile Regression Approach", International Policy Center Working Paper Series Number 56.

Oaxaca, R. (1973), "Male-Female Wage Differentials in Urban Labor Markets", International Economic Review, vol. 14, pp. 693-709.

Oaxaca, R. \& Ransom, M. (1994), "On discrimination and decomposition of wage differentials", Journal of Econometrics, vol. 61, pp. 5-21.

Oettinger, G. (1996), "Statistical Discrimination and the Early Career evolution of the Black White Wage Gap", Journal of labor Economics, 14(1), pp. 52-78.

Pailhé, A. \& ponthieux, S. (2008), "Descendantes d'immigrés en France : une double vulnérabilité sur le marché du travail", Travail, Genre et Sociétés, n $^{\circ}$ 20, novembre,pp. 87-107.

Phelps, E. (1972), "The Statistical Theory of Racism and Sexism", American Economic Review, 62(4), pp. 659-661.

Silber, J. \& Weber, M. (1999), "Labour Market Discrimination : Are there Significant Differences between the various Decomposition Procedures?", Applied Economics, Taylor and Francis Journals, vol. 31(3), pp. 359-365.

Zellner, H. (1972), "Discrimination Against Women, Occupational Segregation, and the Relative Wage", American Economic Review, 62(2), pp. 157-160. 